\title{
Identifikasi Kreativitas Siswa Terhadap Mata Pelajaran IPA
}

\author{
Slamet Harahap ${ }^{1}$ \\ ${ }^{1}$ SMPN 22 Kota Jambi, Jambi, Indonesia
}

\begin{tabular}{l}
\hline Article Info \\
\hline Article history: \\
Received Dec 28, 2019 \\
Revised Dec 29, 2019 \\
Accepted Dec 31, 2019
\end{tabular}

\section{Keywords:}

Kreativitas

Siswa

IPA

\begin{abstract}
Tujuan penelitian: Penelitian ini adalah untuk mengetahui kreativitas siswa terhadap mata pelajaran IPA di SMP 22 Kota Jambi pada indikator Lancar dalam mengekspresikan ide secara lisan dan tertulis, Tidak ada masalah ketika dihadapkan dengan masalah Senang dengan hal-hal yang menantan, Hargai kesempatan itu.

Metodologi: Penelitian ini menggunakan metode kuantitatif menggunakan kuesioner. Sampel yang digunakan dalam penelitian ini adalah 101 siswa di SMPN 22 Kota Jambi. Teknik analisis data yang digunakan adalah statistik deskriptif.

Temuan Utama: Saran yang ditunjukkan dalam studi lain yang serupa dan guru mata pelajaran sains di sekolah menengah pertama diharapkan studi lain dapat menjadi spesifik dalam menggambarkan kreativitas siswa belajar mata pelajaran sains dan yang kedua dengan penelitian ini diharapkan dapat menjadi referensi sebagai persiapan bagi guru sains untuk dapat memahami dan membantu siswa dalam mengembangkan kreativitas siswa untuk kursus dari IPA dalam rangka mencapai hasil yang optimal

Keterbaruan Penelitian: Peneliti melakukan penelitian ini karena kesegaran penelitian ini menggunakan indikator untuk menggambarkan kreativitas siswa untuk pelajaran IPA di SMPN 22 Kota Jambi. Indikator yang digunakan adalah Lancar dalam mengekspresikan ide secara lisan dan tertulis, Tidak ada masalah ketika dihadapkan dengan masalah, Senang dengan hal-hal yang menantang, Menghargai peluang. Setelah mengamati peneliti mendapatkan data yang dapat dijelaskan sebagai berikut
\end{abstract}

This is an open access article under the $\mathrm{CC} B Y-N C$ license

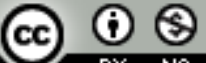

\section{Corresponding Author:}

Slamet Harahap,

Guru Pendidikan Fisika, SMPN 22 Kota Jambi

Jl. Thalib Fachruddin No. 10 Kenali Besar, Kota Jambi, 36361, Indonesia

Email: slhap123@gmail.com

\section{PENDAHULUAN}

Sebagai negara berkembang untuk menghadapi dunia kompetitif Indonesia harus dapat melakukan pembangunan di berbagai bidang, tidak terkecuali di bidang pendidikan. Pendidikan adalah fondasi utama dalam mempersiapkan generasi penerus untuk mencapai cita-cita bangsa [1]. Education is a processing effort by someone to get knowledge, skills, and habits in life [2]. Education is a conscious and planned effort to create an atmosphere of learning and learning process so that students actively develop their potential[3]. Menurut [4] yang mengatakan bahwa pendidikan adalah suatu kegiatan yang sangat penting bagi semua manusia, yang dapat merubah tingkah laku dan pengetahuan menjadi lebih baik. Education in the present very much requires the use of technology to improve the competence of increasing human resources. because now is the era of industrial revolution 4.0 [5]. Advances in technology have influenced students in their 
learning process [6]. Dengan adanya pendidikan, manusia dapat merubah tingkah laku dan pengetahuan menjadi lebih baik [7]. Indonesia dikatakan sebagai kunci keberhasilan perbaikan dan upaya membangun bangsa, untuk memiliki standar hidup yang lebih baik. Dengan pendidikan mereka dapat meningkatkan sumber daya manusia yang mampu bersaing dengan bangsa lain. Pendidikan adalah proses berkelanjutan yang bertujuan untuk meningkatkan kualitas sumber daya manusia [8].

Implementasi pendidikan dapat dilakukan dalam proses pembelajaran di sekolah. In addition to understanding the material, what the prospective teacher does is to plan, implement and evaluate innovative learning through learning [9]. Setiap jenjang pendidikan memiliki karakteristik berbeda pada ilmu pengetahuan yang di pelajari. Sesuai dengan perkembangan dari peserta didik itu sendiri seperti siswa SMA yang tidak akan sama dengan siswa SD dan SMP [10].

Guru adalah elemen kunci dalam proses pembelajaran. Keberhasilan proses pembelajaran dipengaruhi oleh kualitas dan cara mengajar seorang guru [11]. Students in the faculty of education are prospective professional educators who have the task of guiding, training and building one's knowledge [12]. Dalam proses pembelajaran yang melibatkan siswa berperan aktif dalam mencapai pendidikan tujuan membentuk karakter pada siswa. Tujuan pendidikan adalah untuk kehidupan intelektual bangsa [13]. Dengan mengetahui karakter dapat membantu guru dalam mengembangkan dan menekankan konsep dalam pembelajaran.

Satu pelajaran sekolah yang perlu menjadi perintah penindasan untuk mendapatkan hasil yang lebih optimal adalah karena matapelajaran IPA IPA matapelajaran digolongkan ke dalam matapelajaran sulit dipahami. IPA sudah dikenalkan dari pendidikan dasar, IPA merupakan pembelajaran yang berproses dan berkelanjutan [14]. Keyakinan, perasaan dan tindakan merupakan tiga komponen utama yang dimiliki sikap ilmiah yang dapat diterapkan melalui penggunaan metode ilmiah untuk membentuk sikap aktif, mandiri, pola pikir kritis, logis dan terstruktur [15]. The scientific attitude is an attitude that must be possessed by students in learning science such as honest, curiosity, responsible, conscientious, discipline, and others [16]. Dengan demikian, program pendidikan sains yang kaya akan metode dan teknik pengajaran yang diikuti oleh siswa secara aktif, memungkinkan platform untuk diskusi dan mengarahkan siswa untuk berpikir dan memproduksi akan efektif dalam pembelajaran [5]. IPA terkait erat dengan alam yang menjadikan pelajaran sains menjadi pelajaran yang agak sulit bagi siswa karena bersifat abstrak [17] Banyak faktor yang menjadi alasan yang membuat IPA menjadi sulit bagi siswa. Yang paling sering adalah faktor siswa harus mengahapal seluruh rumus yang diberikan oleh guru yang merupakan cara pembelajaran konvensional [18]. Untuk itu untuk memahami pelajaran IPA dibutuhkan karakter positif dari siswa yang mampu membantu siswa lebih memahami konsep IPA.

Salah satu karakter yang dapat membantu siswa dalam proses pembelajaran adalah kreativitas belajar. Kreativitas didefinisikan secara berbeda oleh para ahli dari sudut pandang masing-masing. Perbedaan dalam sudut pandang ini menghasilkan beberapa definisi kreativitas dengan berbagai penekanan [19]. Siswa yang memiliki kreativitas belajar yang baik dapat melalui kegiatan penyelesaian masalahnya sehingga siswa akan lebih mampu memahami pelajaran sains. Untuk mengukur krativitas siswa dalam kursus dari IPA membutuhkan indikator yang diadopsi dari penelitian [20] dengan Cronbach alpha 0,977, penelitian Chorus [21-22] dengan Cronbach alpha 0,753 sebanyak 31 pernyataan yang terdiri dari 24 pernyataan positif dan 7 pernyataan negatif. Kuesioner toleransi di adopsi dari penelitian [23] dengan Cronbach alpha sebesar 0,777 sebanyak 32 pernyataan yang terdiri dari 28 pernyataan positif dan empat pernyataan negatif.

1) Lancar dalam mengekspresikan ide secara lisan dan tertulis

2) Tidak ada masalah saat dihadapkan dengan masalah

3) Senang dengan hal-hal yang menantang

4) Menghargai kesempatan yang diberikan

Indikator pertama fasih dalam mengekspresikan ide secara lisan dan tertulis. Ini berarti bahwa ketika siswa mampu memberikan gagasan tentang pemasalahan IPA siswa-siswanya memiliki tingkat kreativitas yang baik. Kreativitas jarang dilihat sebagai hasil pembelajaran kritis dari pendidikan tersier [24]. Jika siswa memiliki ide untuk memcahkkan masalah dan berani mengekspresikan kreativitasnya pembelajaran dapat membantu siswa dalam memahami pelajaran sains. Indikator kedua Tidak ada masalah saat dihadapkan dengan masalah. Siswa yang memiliki keteramplan belajar yang baik tidak akan mengalami kesulitan ketika diberi masalah dalam pelajaran sains [25]. Ini akan mengarah pada keinginan pada siswa untuk menemukan solusi untuk masalah ini. Siswa dengan kreativitas tinggi akan dapat belajar dengan baik karena ia selalu memiliki ide-ide kreatif yang dapat meningkatkan motivasi belajar. Siswa juga akan selalu berusaha menemukan sesuatu yang baru dalam hidupnya [26]. Siswa yang telah mempelajari kreativitas akan menganggap masalah dalam kursus dari IPA sebagai tugas mudah bagi siswa yang memiliki ide untuk menyelesaikan Indikator ketiga Senang dengan hal-hal yang tantangan. Siswa yang telah mempelajari 
kreativitas akan selalu merasa tertantang ketika diberikan IPA meskipun ada masalah yang sulit. Kreativitas adalah suatu proses yang dapat dikembangkan dan ditingkatkan [27], Siswa dengan krativitas belajar yang baik akan berusa merasa tertantang dan berusaha mencari solusi dan solusi untuk suatu masalah. Kemudian indikator keempat menghargai peluang. Siswa yang telah mempelajari kreativitas juga tidak akan menyianyiakan kesempatannya, Siswa dengan kreativitas belajar yang baik akan mencoba memamanfaatkan segala sesuatu dengan mencoba memahami pelajaran sains yang lebih dalam.

Oleh karena itu untuk menentukan tingkat kreativitas belajar siswa dapat membantu guru dalam proses belajar sains dan memberikan pengetahuan yang cukup tentang bagaimana mengidentifikasi kreativitas siswa terkait pelajaran IPA, dan dampak positif pada siswa sehingga dapat meningkatkan pemahaman siswa tentang sains pelajaran. Sikap peserta didik terhadap mata pelajaran IPA dapat dilihat melalui ekspresi suka ataupun tidak suka [28]. Salah cara yang dapat menarik minat siswa dalam pembelajaran IPA adalah ketika melakukan kegiatan praktikum, karena siswa dapat melakukan teori yang dipelajari dalam kehidupan nyata. Praktikum adalah pembelajaran untuk membuktikan prinsip dan konsep melalui kegiatan eksperimen di laboratorium [29]. Dengan adanya kegiatan praktikum dapat meningkatkan keterampilan proses sains siswa Menurut [30]. Instruksi praktikum sebagai salah satu sumber belajar dalam kegiatan praktis harus menjadi panduan bagi siswa dalam mengembangkan keterampilan proses sains. Keterampilan proses sains dapat digunakan untuk menemukan masalah, penelitian ilmiah, memperoleh informasi ilmiah dan menjeneralisasikannya [31]. Kreativitas merupakan salah satu acuan yang ingin dicapai dalam keterampilan yang dikhususkan pada keterampilan proses [32]. Keterampilan juga termasuk perilaku penting dari diri seseorang. Students who have science process skills can practice understanding the concepts they have acquired in learning activities which have two categories, basic science process skills and integration science process skills [33]. Terutama bagi guru sebagai seorang pendidik. Sebagai guru tenaga pendidik yang profesional, guru memiliki tugas untuk membimbing, melatih serta membangun pengetahuan seseorang [34]. Science process skills needed by the students as prospective teachers to have pedagogic competence which is expected to be a time of skills and expertise directly into the field [35]. Science education study program has a goal to produce graduates who are skilled in various aspects of competence, especially skill competence [36]. Because science process skills emphasize the learning process, accreditation, creativity, values and also the attitude of a student who will later be applied in daily life, so science process skills have a relationship with the motivation of a student [37].

Tujuan dari penelitian ini adalah untuk mengetahui kreativitas siswa terhadap pelajaran IPA di SMPN 22 Kota Jambi. Dalam penelitian ini pertanyaan yang ditampilkan adalah 1) Bagaimana kreativitas belajar siswa dalam hal indikator Lancar dalam mengekspresikan ide secara lisan dan tertulis 2) Bagaimana kreativitas belajar siswa dalam hal indikator Tidak ada masalah saat dihadapkan dengan masalah 3) Bagaimana Kreativitas siswa belajar dalam hal indikator senang dengan hal-hal yang menantang 4) Bagaimana Kreativitas siswa belajar dalam hal indikator Menghargai peluang. Sehingga berdasarkan hasil pengamatan yang dilakukan di SMPN 22 Kota Jambi peneliti ingin mengetahui kreativitas siswa dalam pelajaran IPA untuk membantu guru dan dampak positif dalam proses pembelajaran IPA.

\section{METODOLOGI PENELITIAN}

Berdasarkan latar belakang dari segi tujuan penelitian desain penelitian yang digunakan oleh para peneliti adalah survey menggunakan metode kuantitatif. Metode penelitian kuantitatif digunakan untuk menguji populasi atau sampel tertentu, pengumpulan data menggunakan instrumen penelitian, analisis data kuantitatif/statistik, yang bertujuan untuk menguji hipotesis yang telah dibuat [38]. Metode ini dipilih karena dapat menggambarkan hasil survei yang dilakukan di SMPN 22 Kota Jambi.

Teknik pengambilan sampel dilakukan dengan menggunakan purposive sampling dengan subjek sebanyak 101 siswa di SMPN 22 Kota Jambi. Tekhni telah melihat deskripsi kreativitas siswa untuk pelajaran sains di SMPN 22 Kota Jambi. Instrumen penelitian adalah kuesioner yang digunakan oleh peneliti untuk mempelajari kreativitas yang merupakan kuesioner tertutup. Kuisioner Kuisioner atau teknik pengumpulan data dimana partisipan/responden mengisi pertanyaan atau pernyataan yang kemudian diisi sepenuhnya dikembalikan kepada peneliti [39]. Skala yang digunakan adaah linkert skala lima poin yang terdiri dari STS = sangat tidak setuju, TS = tidak setuju, N = netral, S = setuju, SS = sangat setuju. Kuisioner Kreativitas di adopsi dari penelitian [20] dengan alpha Cronbach sebesar 0,977.

Prosedur yang dilakukan dalam penelitian ini adalah kuesioner yang disebaran kemudian melakukan analisis data kreativitas belajar siswa diikuti dengan mentranskip seluruh data yang diperoleh selama penelitian ke dalam tabel hasil. Analisis data yang digunakan dalam penelitian ini adalah analisis deskriptif. Statistik deskriptif adalah statistik yang dimaksudkan untuk menganalisis sekumpulan data dengan merangkum, menyajikan, dan memberikan penjelasan atau deskripsi tentang karakteristik dasar sampel 
berdasarkan data yang tersedia [40]. Data yang diperoleh adalah mean, mode, median, maksimum, minimum, dan standar deviasi, persentase, frekuensi menggunakan SPSS 22.

\section{HASIL DAN PEMBAHASAN}

Peneliti melakukan penelitian ini karena kesegaran penelitian ini menggunakan indikator untuk menggambarkan kreativitas siswa untuk pelajaran IPA di SMPN 22 Kota Jambi. Indikator yang digunakan adalah Lancar dalam mengekspresikan ide secara lisan dan tertulis, Tidak ada masalah ketika dihadapkan dengan masalah, Senang dengan hal-hal yang menantang, Menghargai peluang. Setelah mengamati peneliti mendapatkan data yang dapat dijelaskan sebagai berikut

\subsection{Lancar dalam mengekspresikan ide secara lisan dan tulisan}

Lancar dalam menuangkan ide-ide secara lisan dan tertulis merupakan salah satu indikator yang menunjukkan kreativitas yang dimiliki siswa dalam belajar, ketika siswa mampu mengekspresikan ide yang diemukakan berarti siswa memiliki cara memecahkan masalah dalam menghadapi sains. Ada beberapa siswa yang mengajukan sesi tanya jawab, dan ada juga beberapa siswa yang memeberikan pendapat, kontribusi ini menunjukkan bahwa peningkatan aktivitas siswa selama kuliah [41].

Hasil pengolahan data dalam indikator saat ini dalam mengekspresikan ide secara lisan dan tertulis.

Tabel 1. Indikator Saat Ini dalam mengekspresikan ide secara lisan dan tulisan siswa di SMPN 22 Kota Jambi

\begin{tabular}{cccccc}
\hline Interval & Kategori & Total & $\%$ & Min & Max \\
\hline $3.0-5.4$ & Sangat Tidak Baik & 5 & 5.0 & & \\
$5.5-7.8$ & Tidak Baik & 10 & 9.9 & & \\
$7.9-10.2$ & Cukup & 57 & 56.4 & 4.00 & 14.00 \\
$10.3-12.6$ & Baik & 22 & 21.8 & & \\
$12.7-15.0$ & Sangat Baik & 7 & 6.9 & & \\
\cline { 1 - 3 } & Total & 101 & 100 &
\end{tabular}

Dari Tabel 1 dapat dilihat tingkat kreativitas siswa dalam indikator Lancar dalam mengekspresikan ide secara lisan dan tertulis dalam pembelajaran IPA di SMPN 22 Kota Jambi dapat dilihat dari tanggapan siswa yang dikategorikan Sangat Tidak Baik sebanyak 0,5\% ( 5 dari 101 siswa) dan untuk kategori Bagus tidak sebanyak 9,9\% (10 dari 101 siswa) dan untuk kategori Netral sebanyak 56,4\% (57 dari 101 siswa), sedangkan untuk kategori Bagus sebanyak 521,8 \% (22 dari 101 siswa) dan untuk kategori Sangat Baik untuk 6, 9\% (7 dari 101 siswa). Dengan skor minimum pada semua pernyataan 4,00 dan skor maksimum 14,00. Berdasarkan analisis data yang diperoleh menunjukkan bahwa sikap siswa pada indikator Lancar dalam mengemukakan gagasan secara lisan dan tulisan di SMPN 22 Kota Jambi dominan kategori netral. Artinya siswa di SMPN 22 Kota Jambi pada indikator saat ini dalam mengekspresikan ide secara lisan dan tertulis rata-rata netral. Dalam pengajaran sains ide-ide abstrak diperlukan untuk menyelesaikan suatu masalah. Hasil pengolahan data pada indikator Tidak masalah ketika dihadapkan dengan masalah.

Tabel 2. Indikator No trouble siswa yang bermasalah di SMPN 22 Kota Jambi

\begin{tabular}{cccccc}
\hline Interval & Kategori & Total & $\%$ & Min & Max \\
\hline $8.0-14.4$ & Sangat Tidak Baik & 0 & 0 & & \\
$14.5-20.8$ & Tidak Baik & 2 & 2.0 & & \\
$20.9-27.2$ & Cukup & 49 & 48.5 & 20.00 & 36.00 \\
$27.3-33.6$ & Baik & 48 & 47.5 & & \\
$33.7-40.0$ & Sangat Baik & 2 & 2.0 & & \\
\cline { 1 - 3 } & Total & 101 & 100 & &
\end{tabular}

Dari tabel 2 dapat dilihat tingkat kreativitas siswa dalam indikator No trouble ketika dihadapkan pada masalah dalam pembelajaran dari IPA di SMPN 22 kota Jambi dapat dilihat dari tanggapan siswa yang dikategorikan Sangat Tidak Baik dari 0\% ( dari 101 siswa) kemudian untuk kategori Tidak Baik sebanyak 2,0\% (2 dari 101 siswa) dan untuk kategori Netral sebanyak 48,5\% (49 dari 101 siswa), sedangkan untuk kategori Baik 47,5\% (48 dari 101 siswa) siswa) dan untuk kategori Sangat Baik sebanyak 2,0\% (7 dari 101 siswa). Dengan skor minimum pada semua pernyataan adalah sebesar 20,00 dan skor maksimum 36,00. Berdasarkan analisis data yang diperoleh menunjukkan bahwa sikap siswa terhadap indikator ini termasuk kedalam kategori netral. Hasil pengolahan data pada indikator Senang dengan hal-hal yang menantang. 
Tabel 3. Indikator Senang dengan hal-hal yang menantang siswa di SMPN 22 Kota Jambi

\begin{tabular}{cccccc}
\hline Interval & Kategori & Total & $\%$ & Min & Max \\
\hline $6.0-1.8$ & Sangat Tidak Baik & 0 & 0 & & \\
$10.9-15.6$ & Tidak Baik & 38 & 38.0 & & \\
$15.7-20.4$ & Cukup & 57 & 57.0 & \multirow{2}{*}{12.00} & 45.00 \\
$20.5-25.2$ & Baik & 6 & 6.0 & & \\
$25.3-30.0$ & Sangat Baik & 0 & 0 & & \\
\hline \multicolumn{7}{c}{ Total } & 100 & 100 & \\
\hline
\end{tabular}

Dari Tabel 3 dapat dilihat tingkat kreativitas siswa dalam indikator Senang dengan hal-hal yang menantang dalam pembelajaran dari IPA di SMPN 22 kota Jambi dapat dilihat dari tanggapan siswa yang dikategorikan Sangat Tidak Baik dari 0\% (dari 101 siswa) dan kemudian untuk kategori Tidak Baik sebesar 38, 0\% (38 dari 101 siswa) dan untuk kategori Netral sebanyak 57,0\% (57 dari 101 siswa), sedangkan untuk kategori Baik sebanyak 6\% ( 6,0 dari 101 siswa) dan untuk kategori Sangat Bagus mulai 0\% (0 dari 101 siswa). Dengan skor minimum pada semua pernyataan 12,00 dan skor maksimum 45,00. Berdasarkan analisis data yang diperoleh menunjukkan bahwa sikap siswa pada indikator Senang dengan hal-hal yang menantang dan posting IPA di SMPN 22 Kota Jambi dominan kategori netral. Hasil pengolahan data pada kesempatan tertentu Indikator Apresiasi.

Tabel 4. Indikator Menghargai peluang yang diberikan siswa di SMPN 22 Kota Jambi

\begin{tabular}{cccccc}
\hline Interval & Kategori & Total & $\%$ & Min & Max \\
\hline $1.0-1.6$ & Sangat Tidak Baik & 2 & 1.2 & & \\
$1.7-2.2$ & Tidak Baik & 6 & 5.8 & & \\
$2.3-2.8$ & Cukup & 20 & 20.0 & 1.00 & 5.00 \\
$2.9-3.4$ & Baik & 41 & 41.0 & & \\
$3.5-4.0$ & Sangat Baik & 32 & 32.0 & & \\
\hline & Total & 101 & 100 & & \\
\hline
\end{tabular}

Dari Tabel 4 dapat dilihat tingkat kreativitas siswa dalam indikator Menghargai peluang yang disajikan dalam pembelajaran dari IPA di SMPN 22 kota Jambi dapat dilihat dari tanggapan siswa yang dikategorikan Sangat Tidak Baik sebanyak 1,2\% (2 dari 101 siswa) dan untuk kategori tidak baik sebesar 5, 8\% (6 dari 101 siswa) dan untuk kategori Netral sebanyak 20,0\% (20 dari 101 siswa), sedangkan untuk kategori Good sebanyak 41,0\% ( 41.0 dari 101 siswa) dan untuk kategori Sangat Baik sebanyak $31.0 \%$ (32 dari 101 siswa). Dengan skor minimum pada semua pernyataan 1,00 dan skor maksimum 5,00. Berdasarkan analisis data yang diperoleh menunjukkan bahwa sikap siswa pada indikator menghargai peluang dengan halhal yang ada di SMPN 22 Kota Jambi kategori dominan Baik.

\section{KESIMPULAN}

Dari hasil analisi data yang terdapat pada Indikato ini menunjukkan hasil yang cukup baik. untuk meningkatkan kreativitas siswa disekolah diharapkan guru dapat berperan penting dalam meningkatkannya. Saran yang ditunjukkan dalam penelitian lain yang serupa dan guru mata pelajaran IPA di sekolah menengah pertama adalah yang diharapkan studi lain dapat menjadi spesifik dalam menggambarkan kreativitas siswa belajar mata pelajaran IPA dan yang kedua dengan penelitian ini diharapkan dapat menjadi referensi sebagai persiapan bagi guru sains untuk dapat memahami dan membantu siswa dalam mengembangkan kreativitas siswa ke kursus dari IPA untuk mencapai hasil yang optimal.

\section{UCAPAN TERIMA KASIH}

Terimakasih kepada kepala sekolah, guru dan responden di SMPN 22 Kota Jambi yang telah memberi kami izin untuk melakukan pengamatan dan terima kasih kepada pihak-pihak yang mendukung dalam proses penelitian ini.

\section{REFERENSI}

[1] Yuliani, S., Tindangen, M., \& Rambitan, F,“Analysis of Teacher Issues Related Devices Guided Inquiry Based Learning Model in Learning Ipa And Problem Solving”. Journal of Education, vol. 2, no. 4, pp.535-539. 2017.

[2] S. Asrial, Syahrial, D. A. Kurniawan, F. Chan, R. Septianingsih, and R. Perdana,"Multimedia innovation 4.0 in education: E-modul ethnoconstructivism”, Univers. J. Educ. Res., vol. 7, no. 10, pp. 2098-2107, 2019. 
[3] S. Syahrial, A. Asrial, D. A. Kurniawan, F. Chan, A. Hariandi, R. A. Pratama, P. Nugrogo, and R. Septiasari,"The impact of etnocontructivism in social affairs on pedagogic competencies", International Journal of Evaluation and Research in Education (IJERE), vol. 8 no. 3, pp. 409-416, 2019.

[4] Astalini, Kurniawan, D. A., Perdana, R. \& Pathoni, H,’Identifikasi Sikap Peserta Didik terhadap Mata Pelajaran Fisika di Sekolah Menengah Atas Negeri 5 Kota Jambi”, Unnes Physics Education Journal, vol.8, no. 1, 2019.

[5] Astalini, A., Kurniawan, D. A., Sulistiyo, U., Perdana,"RE-Assessment Motivation in Physics Subjects for Senior High School”. International Journal of Online and Biomedical Engineering (iJOE). Vol.15, no.11, 2019.

[6] Asrial, Syahrial, D. A. Kurniawan, R. Perdana, and P. Nugroho. "Supporting Technology 4.0: Ethoconstructivist Multimedia for Elementary Schools", International Journal of Online and Biomedical Engineering (iJOE). Vol. 15 No. 14, pp. 54-66, 2019.

[7] Astalini., D. A Kurniawan, D. K. Sari \& W. Kurniawan,'Description of Scientific Normality, Attitudes of Investigation and Interested Career On Physics in Senior High School". JIPF (Jurnal Ilmu Pendidikan Fisika), 2019.

[8] Darmaji, D.A. Kurniawan, and A.Suryani,"Effectiveness of Basic Physics II Practicum Guidelines Based On Science Process Skills". JIPF (Journal of Physical Education), vol 4, no. 1, pp.1-7. 2019.

[9] A. Asrial, S. Syahrial, D. A. Kurniawan, F. Chan, P. Nugrogo, R. A. Pratama, and R. Septiasari," "Identification: The effect of mathematical competence on pedagogic competency of prospective teacher," Humanit. Soc. Sci. Rev., vol. 7, no. 4, pp. 85-92, 2019.

[10] Astalini. Kurniawan, D A \& Sumaryanti,"Sikap Siswa Terhadap Pelajaran Fisika Di Sman Kabupaten Batanghari”. Jurnal Ilmu Pendidikan Fisika, Vol.3, no.2, Pp. 59-64, 2018.

[11] Darmaji, DA, D. A. Kurniawan, A. Suryani, and A. Lester, “An Identification of Physics Pre-Service Teachers' Science Process Skills Through Science Process Skills-Base Practicum Guidebook”. Scientific Journal of Physical Education Al-Biruni, vol. 7, no. 2, pp.239-245. 2018.

[12] A. Asrial, S. Syahrial, D. A. Kurniawan, M. Subandiyo, and N. Amalina. "Exploring Obstacles in Language Learning Among Prospective Primary School Teacher," International Journal of Evaluation and Research in Education (IJERE), vol. 8 no. 2, pp. 249-254, 2019.

[13] Sukasni, A., \& Efendy, H. "The Problematic of Education System in Indonesia and Reform Agenda". International Journal of Education, vol 9, no. 3, 183.https://doi.org/10.5296/ije.v9i3.11705. 2017.

[14] Astalini, D. A. Kurniawan, R. Perdana, and W. Kurniawan, "Journal of Educational Science and Technology," $J$. Educ. Sci. Technol., vol. 5, no. 1, pp. 39-48, 2019.

[15] Astalini, K. Dwi Agus, and Sumaryanti, "Sikap S Iswa T Erhadap P Elajaran F Isika Di Sman K Abupaten Batanghari," J. Ilmu Pendidik. Fis., vol. 3, no. 2, pp. 59-64, 2018.

[16] D. A. Kurniawan, Astalini, A. Susanti, and Maison, "Attitudes of College Students on the Subject of Mathematical Physics III in Physics Education Program of Jambi University,” Educ. Rev. USA, vol. 2, no. 11, pp. 505-513, 2018.

[17] Astalini, D. A. Kurniawan, R. Perdana, and W. Kurniawan, "Journal of Educational Science and Technology," $J$. Educ. Sci. Technol., vol. 5, no. 1, pp. 39-48, 2019.

[18] Astalini, D. A. Kurniawan, R. Melsayanti, and A. Destianti, "Sikap Terhadap Mata Pelajaran IPA Di SMP SeKabupaten Muaro Jambi," Lentera Pendidik., 2018.

[19] N. Sener, C. Türk, \& E. Taş, “Improving Science Attitude and Creative Thinking through Science Education Project: A Design, Implementation and Assessment”. Journal of Education and Training Studies, vol 3, no. 4, 57 67. https://doi.org/10.11114/jets.v3i4.771. 2015.

[20] D.A. Nafiaty, "Motivation, Creativity, and Self-Confidence as Forming Factors of Economic Learning Autonomy. Dynamics of Education", vol 12, no. 2, 182-195. DOI: 10.15294 / dp.v12i2.13566. 2017.

[21] F. P. Nursa'adah, \& N. M. Rosa, "Chemical analysis of the ability of Creative Thinking Judging from the Adversity Quotient, Scientific Attitude and Interest in Learning”. Formative Journal, vol 6, no. 3, pp. 197-206. 2016.

[22] Suciartini, NNA. "Urgency Tolerance Education in the Face of Education voted to Increase the Quality of Education”. Quality Assurance Journal, vol 3, no. 1, pp. 12-22. 2017.

[23] Astalini, Maison, M. Ikhlas, and D. A. Kurniawan, "Pengembangan Instrumen Sikap Mahasiswa Terhadap Mata Kuliah Fisika Matematika,” EDUSAINS, vol. 10 no. 1, pp. 46-52, 2018.

[24] R. Ismail, “Concept of Tolerance in Psychology of Religion (Review for Religious Maturity)”. Religion Religions Studies Journal, vol 8, no. 1, pp. 1-12. 2012.

[25] Z. Fieldz, \& C. Bisschoff,"Developing and Assessing a tool to measure the Creativity of University Student”. J Soc Sci, vol 38, no. 1, pp. 23-31. 2014.

[26] Astalini, D.A. Kurniawan, N. Kurniawan, \& L. Anggraini,"Evaluation of Student's Attitude toward Science in Indonesia", Open Journal for Educational Research, vol. 3, no.1, pp.1-12, 2019.

[27] Darmaji, D. A. Kurniawan, \& A. Lestari,'Deskripsi keterampilan proses sains mahasiswa pendidikan fisika pada praktikum suhu dan kalor", JRKPF UAD, vol.5, no.2, 2018.

[28] Darmaji, D. A. Kurniawan, \& A. Rahayu,'Development Physics Practical Guided Based On Science Process Skill Using Problem Solving. Edusains, vol.10, no.1, pp.83-96,2018.

[29] Darmaji, D. A. Kurniawan, \& A. Suryani,"'Effectiveness of Basic Physics II Practicum Guidelines Based On Science Process Skills". JIPF (Jurnal Ilmu Pendidikan Fisika), vol.4, no.1, pp.1-7, 2019. 
[30] Darmaji, D. A. Kurniawan, H Parasdila, I Irdianti\& A. Lestari,'Deskripsi keterampilan proses sains mahasiswa pendidikan fisika pada praktikum suhu dan kalor". Berkala Ilmiah Pendidikan Fisika, vol.6, no.3, pp.345-353, 2018.

[31] Darmaji, D. A. Kurniawan, A. Suryani, \& A. Lestari, A,”An Identification of Physics Pre-Service Teachers' Science Process Skills Through Science Process Skills-Based Practicum Guidebook", Jurnal Ilmiah Pendidikan Fisika Al-Biruni, vol.7, no. 2, pp. 239-245, 2018.

[32] Darmaji, D. A. Kurniawan, and A. Suryani, "Effectiveness of Basic Physics II Practicum Guidelines Based On Science Process Skills," J. ILMU Pendidik. Fis., vol. 4, no. 1, pp. 1-7, 2019.

[33] Darmaji, D. A. Kurniawan, H. Parasdila, and Irdianti, "Deskripsi Keterampilan Proses Sains Mahasiswa pada Materi Termodinamika," Berk. Ilm. Pendidik. Fis., vol. 6, no. 3, pp. 345-353, 2018.

[34] Darmaji, D. A. Kurniawan, H. Parasdila, Irdianti, S. Hadijah, and R. Perdana, "Practicum Guide: Basic Physics Based Of Science Process Skill,” Humanit. Soc. Sci. Rev., vol. 7, no. 4, pp. 151-160, 2019.

[35] Darmaji, D. A. Kurniawan, H. Parasdila, and Irdianti, "Description of Science Process Skills ' Physics Education Students at Jambi University in Temperature and Heat Materials," Educ. Rev., vol. 2, no. 9, pp. 485-498, 2018.

[36] Wilda, dkk. "Influence Of Creativity And Interest in Learning Mathematics Learning Outcomes Student Creativity And Interests effect BelajarTerhadap Math Student Learning Outcomes". Pedagogy Journal, vol 2 no 1. 2016.

[37] Suhadi, Octen, "Strengthening. Character Education (PPK) for SMA / MA". Jakarta: Erland. 2018.

[38] Sugiyono,"Methods Combination (Mix Methods)". Bandung. Alfabeta. 2018.

[39] Sugiyono,"Statistics For Research". Bandung: Albeta. 2012.

[40] Suwarjana. Health Statistics. Yogyakarta: Andi Offset. 2016.

[41] Awaluddin, Murtiadi, "Strengthening the Role of Work Environment and Culture Organizations in the Optimizing Performance Alauddin State Islamic University lecturer Makassar through job satisfaction". Journal of Management, Idea, Inspiration (MINDS), vol 5, no. 1, 53-67. 2018. 